\title{
Secondary Study Sponsor Name
}

National Cancer Institute

\section{Source}

National Cancer Institute. Secondary Study Sponsor Name. NCI Thesaurus. Code

C139169.

The name of the entity that is considered the secondary sponsor for the trial or study. 